IN THE RED CROSS WORLD

b) Nursing

- Nurses

- Auxiliary Nursing Personnel

- Home Nursing

- Dissemination of the 1949 Geneva Conventions among Nursing Personnel.

c) Junior Red Cross

- Protection of Health and Life

- Junior Red Cross International Service Programme (including assistance to new National Societies)

- Dissemination of the 1949 Geneva Conventions.

d) The future work and development of the Red Cross.

4. Recommendations and Conclusions.

\title{
Drafting CommitreE
}

1. Election of Chairmen, Members and Secretaries.

2. Drafting and Co-ordination of Resolutions.

\section{Belgium}

\section{Florence Nightingale Medal}

It will be recalled that on December 13, 1961, Mrs. Nicole Vroonen, voluntary aid ambulance driver, died in tragic circumstances in the Congo whilst carrying out a Red Cross mission with Mr. Georges Olivet and Mr. Styts Smeding, who were also killed at the same time. ${ }^{1}$ On the proposal of the Belgian Red Cross, the Commission for the Florence Nightingale Medal decided to award this distinction to her posthumously. This was accordingly announced to the Red Cross world by the ICRC in its circular No. 441 of May 12, 1963.

1 See International Review, January 1962.

Plate : H.R.H. Prince Albert, President of the Belgian Red Cross, presenting the Florence Nightingale diploma and medal to Mrs. Nicole Vroonen's mother. 


\section{IN THE RED Cross WoRLD}

Last November at a national general session organized by the Belgian Red Cross in tribute to those who work for it and to its blood donors, the President of the Society, H.R.H. Prince Albert presented to Mrs. Bungart, Mrs. Nicole Vroonen's mother, the Medal and Diploma awarded for having made the supreme sacrifice in the accomplishment of a mission.

\section{Korea}

Democratic Republic

A large selection of photographs which the Red Cross of the Democratic People's Republic of Korea sent to the ICRC gives a vivid picture of the effective activities carried on by that National Society. The wide variety of these activities and the initiative they reveal are striking. They range from delicate eye and brain surgery in the hospitals at Pyongyang and the treatment of infantile paralysis under our common emblem to the example of goodwill by the members of the Junior Red Cross who do useful work such as amongst other things, caring for the lawns in front of the Grand Theatre or in the residential districts of the capital. ${ }^{1}$

\section{Lebanon}

Last November, the Lebanese Red Cross held its seventh Annual Congress, the theme being "The Red Cross and national and international emergency relief ". Four hundred persons took part in the meetings which were held simultaneously in Arabic and French. After an address of welcome by the Society President, Mrs. A. Issa-el-Khoury, several papers were presented by members

\footnotetext{
${ }^{1}$ Plate. The Junior Red Cross makes itself useful to society in Pyongyang.
} 